\title{
Vibration Analysis of the Engine Using Biofuel Blends: A Review
}

\author{
Erdiwansyah $^{1,2}$, M.SM Sani ${ }^{1}$, Rizalman. Mamat ${ }^{1}$, Fitri Khoerunnisa ${ }^{3}$, AR Rajkumar ${ }^{4}$, \\ N.F.D Razak ${ }^{1}$, R.E Sardjono ${ }^{3}$, \\ ${ }^{1}$ Faculty of Mechanical Engineering, Universiti Malaysia Pahang, Pekan, Pahang 26600 Malaysia \\ ${ }^{2}$ Fakultas Teknik, Universitas Serambi Mekah Aceh 23249, Indonesia \\ ${ }^{3}$ Department of Chemistry, Universitas Pendidikan Indonesia \\ ${ }^{4}$ Gnanamani College of Technology, India
}

\begin{abstract}
The vibrations and noise of the internal combustion engine may be affected by several factors such as combustion pressure, movement of the piston-crank mechanism, coolant factor flow, engine body, and fuel inlet of the injector. Various ways have been done to reduce vibration and noise in the engine, including fuel. Alternative biofuels can be used in internal combustion engines without having to modify and change parameters on the machine. Several researchers have studied the effects of vibration and noise in the engine using various fuel mixtures. The results from some literature reported that biodiesel blend fuels proved to reduce vibration and noise in engines as compared to pure diesel. Meanwhile, ethanol fuel mixed with gasoline shows significant vibration changes at engine speeds of 1,500 and $2,500 \mathrm{rpm}$. The review aims to analyse the effects of vibration and noise on engines fueled by fuel mixtures, as well as fuel properties used as a move for future research. Based on the analysis from several kinds of literature, it shows that the use of biodiesel fuel and ethanol-gasoline can reduce vibration and noise.
\end{abstract}

\section{Introduction}

Nowadays, many automotive parts companies have created a variety of engines, especially for vehicle engines, and a wide range of the latest technologies used on machines to attract the attention of users. The latest vehicle engine is now more sophisticated. However, there are still many problems that can severely bring about disruption as some engines cause discomfort to passengers [1-3]. The most common problems with the machines are vibration and sound of burning. Vibration and noise factors, such as combustion pressure, inputs occurring from the work of the engine fittings, the movement of the crank-piston mechanism, the flow of problem agent, the engine body, the water fuel and the exit of the appliance, the upper impact, the inertia of the cam unit, and incoming and outgoing gases.

Several researchers have studied on the vibration and noise characteristics of internal combustion engines punctured by various fuel mixtures. Investigations regarding the characteristics of vibration, emissions, and performance of diesel engines using blended fuels from biodiesel have been conducted by [4, 5]. Investigations have been carried out with regard to the vibration behaviour on spark ignition engines fuelled by a mixture of methanol, 
unleaded gasoline, and ethanol [6-8]. The vibration effect on a compression-ignition (CI) engine fuelled by ethanol fuel added to diesel has been studied by [9]. According to their experiments, the D94E6 fuel mixture showed the RMS and the vibration kurtosis contained in the engine block increased by $4.75 \%$ and $7.75 \%$ as compared to pure diesel fuel, as diesel fuel exhibited a few more shocks. On the other hand, the average torque value increased by $3.8 \%$ as compared to pure diesel fuel. Vibration investigations on small engines using dieselbiodiesel fuel have been investigated by [10]; the results of the tests found that all engine speeds can match the frequency of stroke on the engine piston and the magnitude of the engine vibration depending on the speed, growing measurement, and mixed fuel used. Significantly, the engine vibration is strongly influenced by the speed of forwarding, which is increased due to the increase in vibration acceleration. The results of several experiments conducted with the fuel mixtures of B100, B5, and B20 showed the lowest vibration. The vibro-acoustic behaviour of small engine displacements on microcars uses mixed fuel biodiesel from refined cooking oil and ultra-low sulphur diesel with volumes up to 40\% [11]. The experimental results showed an increase in index noise for all fuel mixtures, where the highest value was found in the B10 mix for most of the tested engine loads. A vibration analysis on a diesel engine fuelled by a blend of biodiesel and Petrodiesel fuel has been investigated by [12]. Experimental results conducted with fuel mixtures of B5, B10, B15, $\mathrm{B} 20, \mathrm{~B} 30, \mathrm{~B} 40$, and B50 at 1,800 and 2,000 rpm engine speeds found that the lowest vibration was at D100 as compared to B100.

A similar study was also conducted by [13], whereby they investigated the effects of biodiesel fuel added to hydrogen on a compression-ignition engine. Pure biodiesel fuels were mixed with low sulphur diesel with volumes of 50\% and 75\%. Experimental results showed that biodiesel fuel can reduce the specific fuel consumption of the brakes. Meanwhile, biodiesel and hydrogen fuel can decrease vibration on the engine and the frequency spectrum decreased from the results transmitted through the engine piston. The vibration, noise, and exhaust emission analyses were carried out using diesel and biodiesel low sulphur dioxide mixtures with volumes of D100, SB20, SB40, CaB20, CaB40, CoB20, and CoB40 on a compression-ignition engine [14]. An investigation has been conducted on vibration and noise-induced fuel vibration between JB100 and JB20 and diesel minerals on a generator set [15]. The experimental results showed that the duration of fuel combustion and variation of $\mathrm{HRR}_{\max }$ can be very well correlated with the measurement of vibration and noise in the combustion engine. The effect of vibration characteristics and noise emissions triggered the fuel ethanol-gasoline blend on the spark ignition engine [16]. The mixed volume is carried out between $25 \%$ E-70\% G-5\% O and 50\% E- $45 \%$ G-5\% O, at the engine speeds of 1,500, 2,000 , and 2,500 rpm. The results of experiments conducted at the time of engine speeds of 1,500 and 2,500 rpm engine vibration characteristics changed significantly. This is because latent heat and oxygen content are higher than ethanol. A similar investigation of noise and vibration in compression engines fuelled by biodiesel fuel has also been investigated by [17]. The experimental results found that increasing the biodiesel ratio can reduce the noise and vibration of the engine. The values of the coefficient of correlation $(\mathrm{R})$ for vibration and noise are 0.784 and 0.741 , respectively. Cinar et al. [18] analysed vibration and noise in diesel engines using diesel and biodiesel with volumes of $20 \%, 50 \%$, and $100 \%$. Results reported that B20 at a load reaches $100 \mathrm{Nm}$ to $35 \%$. The amplitude of engine vibration increases when compared to diesel fuel.

The results of previous researches that showed the effects of vibration and noise on the machine have brought about an interesting topic to be studied by various researchers around the world. This study aims to analyse the impact of vibration and noise on the engine when using different fuel mixtures and engine loads. This analysis includes various fuels as well as the machines used in the experiment. Fuel properties are also analysed based on the volume of ratios used. 


\section{The commonly used fuel}

\subsection{Diesel fuel}

Diesel fuel processing evaporates more slowly than gasoline or alcohol-based fuels; this is because diesel weighs more than gas that evaporates faster. The content of atoms contained in diesel is much more than gasoline; diesel fuel has a long chain, which is usually known as $\mathrm{C}_{14} \mathrm{H}_{3} \mathrm{O}$, while gas is $\mathrm{C}_{9} \mathrm{H}_{2} 0$. Making solar only requires a little purification, so the price is lower than gasoline. The increase in diesel demand is much higher than gasoline, as in 2004, China and the U.S. used it for construction and industrialisation. Several researches that used diesel fuel to investigate various problems on the machine either by using pure diesel or making some suitable mixture have also included the investigation of vibration and noise effects. From the test results, it can be reported that when using mixtures such as biodiesel, ethanol, methanol, and gasoline, there is a significant change as compared to using pure diesel [8-19]. The experimental results using diesel fuel and some other mixtures are as shown in Table 3.

\subsection{Biodiesel fuel}

Biodiesel is one of the renewable energy that may be made within the country like animal material, used cooking oil, and vegetable oil. Biodiesel fuels like biomass-based ones are able meet all the requirements of renewable biofuel standards. Liquid fuels, such as biodiesel known as B100, are pure biodiesel that can be used on compression combustion engines. The characteristics of biodiesel can be seen in Table 1[19]. Biodiesel blends, diesel characteristics, and raw materials significantly determine their performance in cold weather. Biodiesel B5 is highly precise in cold weather temperatures. Biodiesel B5 with diesel No. 2 has similarities as it crystallises at cold temperatures. Biodiesel production can be executed from agricultural products such as sunflower, soybeans, vegetable oil waste, hemp, canola, jatropha, and sawn oil. Figure 1 shows the system of processing and use of the vehicle.

Table 1. Physical characteristic biodiesel [19]

\begin{tabular}{|l|l|l|l|}
\hline Oxygen, by dif. wt $\%$ & 11 & Sulfur, wt $\%$ & $0.0-0.0015$ \\
\hline Flashpoint, ${ }^{\circ} \mathrm{C}$ & $100-170$ & Kinematic viscosity at $40^{\circ} \mathrm{C}$ & $4.0-6.0$ \\
\hline Density, lb/gal at $15.5^{\circ} \mathrm{C}$ & 7.3 & Lower heating value, Btu/gal & $\sim 119,550$ \\
\hline Specific gravity & 0.88 & Pour point, ${ }^{\circ} \mathrm{C}$ & $-5-10$ \\
\hline Cetane number & $47-65$ & Cloud point, ${ }^{\circ} \mathrm{C}$ & -3 to 15 \\
\hline
\end{tabular}

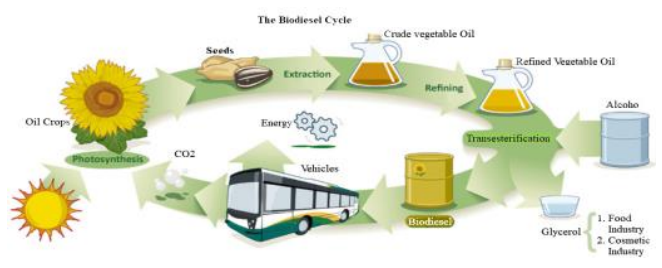

Fig. 1. Biodiesel and fermentation process

\subsection{Ethanol fuel}

Renewable fuels such as ethanol can be made from a variety of plant materials often known as biomass. Gasoline fuels in the United States contain $98 \%$ ethanol, a very suitable 
mixture to oxidise fuel and reduce air pollution (90\% gasoline and ethanol 10\%). The flexible fuels such as ethanol, known as E85, can be used flexibly as vehicle fuels, designed to operate on a fuel mixture between ethanol and gasoline, which reaches $85 \%$. In 2001 , it was also approved for a different fuel blend, i.e. E15, as a new fuel for vehicles. There are many steps concerned in creating alcohol obtainable as a vehicle fuel:

- Biomass feedstocks are grown, accumulated, and transported to an ethanol manufacturing facility.

- Feedstocks are reborn to grain alcohol at a production facility once they are transported to a hydrocarbon terminal or end-person via rail, truck, or barge.

- $\quad$ Ethanol is mixed with gas at the gas terminal to make E10, E15, or E85, after which it is allotted with the aid of truck to fuelling stations.

The materials and processes of producing ethanol fuels from various plant materials such as sugar, starch, and cellulose through the manufacturing system to the extent of their use are as shown in Figure 2.

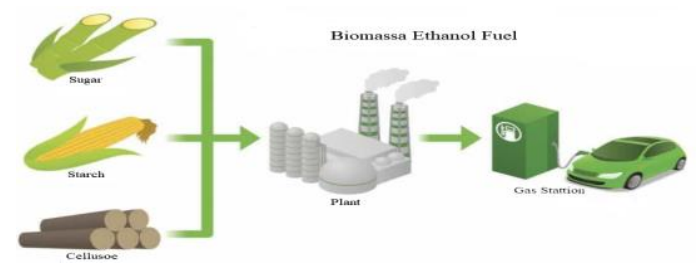

Fig. 2. Biomass ethanol fuel

\subsection{Methanol fuel}

Methanol is a secure, fee-effective alternative marine gas. With the growing demand for purifier marine gasoline, methanol is a promising opportunity gasoline for ships that facilitates the shipping enterprise to meet stricter emission rules. Methanol extensively reduces the emissions of nitrogen oxides (NOx), particulate remember, and sulphur oxides (SOx). Methanol fuel is available worldwide via existing international infrastructure. The fee to construct new and convert present vessels to run on methanol is substantially less than alternate gas conversions. The research using methanol fuels for vehicles has been widely used in recent decades. Tomassetti et al. conducted experiments using methanol fuel [20]. Some researchers $[6,21-25]$ performed a study on several different machines with different results as well. Table 2 displays the difference between properties possessed by methanol fuel and ethanol.

Table 2. Physicochemical properties methanol, ethanol, diesel, and gasoline [26, 27]

\begin{tabular}{|l|l|l|l|l|}
\hline \multicolumn{1}{|c|}{ Property } & \multicolumn{1}{c|}{ Methanol } & \multicolumn{1}{c|}{ Ethanol } & \multicolumn{1}{c|}{ Diesel } & \multicolumn{1}{c|}{ Gasoline } \\
\hline Heat of vaporization $(\mathrm{kJ} / \mathrm{kg})$ & 1162.64 & 918.42 & 243 & 349 \\
\hline Boiling point $\left({ }^{\circ} \mathrm{C}\right)$ & 65 & 78 & $180-370$ & $27-225$ \\
\hline Autoignition temperature $\left({ }^{\circ} \mathrm{C}\right)$ & 463 & 420 & $\sim 300$ & 257 \\
\hline Low heating value $(\mathrm{MJ} / \mathrm{kg})$ & 20.1 & 26.9 & 42.5 & 42.7 \\
\hline Stoichiometric air/fuel ratio & 6.47 & 9.01 & 14.3 & 14.7 \\
\hline Flash point $\left({ }^{\circ} \mathrm{C}\right)$ & 12 & 13 & $65-88$ & -13 to 45 \\
\hline RON & 136 & 129 & $20-30$ & $80-99$ \\
\hline Cetane number & 3.8 & $5-8$ & $40-55$ & $0-10$ \\
\hline
\end{tabular}




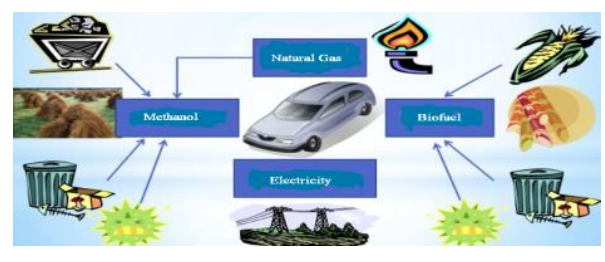

Fig. 3. Commodity fuel methanol.

\section{Effect vibration and noises for fuel blends on engine}

The reciprocating on the engine piston $(\mathrm{P})$, crankshaft (radius $\mathrm{r}$ ), and connecting rods can be seen in Figure 4 . The crank rotation counter clockwise follows the angular velocity $\omega=$ $2 \pi \mathrm{n} / 60$, and the point $\mathrm{O}$ is the highest piston place. Equations (1) And (2) can express the acceleration $(€ \mathrm{XP})$ and displacement $(\mathrm{XP})$ piston in the machine. The connecting rod is centred in the vertical acceleration ( $€ \mathrm{Xc})$ and lateral $(\ddot{\mathrm{Y}} \mathrm{c})$ as presented in Equations (3) and (4) [9].

$$
\begin{aligned}
& X_{P} \approx r\left(1 \frac{r}{2 l}\right)-\left(\cos \omega t+\frac{r}{2 l} \cos ^{2} \omega t\right) \\
& X_{P} \approx r \omega^{2}\left(\cos \omega t+\frac{r}{l} \cos 2 \omega t\right) \\
& X_{C}=r \omega^{2} \cos \omega t \\
& \mathrm{YC}=\mathrm{r} \omega 2 \sin \omega \mathrm{t}
\end{aligned}
$$

Piston mass and crank pin can be assumed with $\mathrm{mP}$ and $\mathrm{mC}$, which are included in the central connecting mass rod of Equation (5) to express the inertial vertical component (Fx). The rotation frequency located on the crankshaft is the same as $\omega$ as the first term, while for the second term, the frequency can be expressed as $2 \omega$. Equation (6) is used to express the horizontal component of the inertial force (Fy) on the cylinder.

$$
\begin{aligned}
& F_{X}=\left(\mathrm{m}_{\mathrm{P}}+\mathrm{m}_{\mathrm{C}}\right) \mathrm{r} \omega^{2} \cos \omega t+\mathrm{m}_{\mathrm{P}} \frac{r^{2} \omega^{2}}{l} \cos 2 \omega t \\
& \mathrm{FY}=-\mathrm{mCr} \omega 2 \sin \omega \mathrm{t}
\end{aligned}
$$

The rotation engine speed is directly proportional to the acceleration in the engine body. Engine mass (mengine) can be considered using Equations (5) And (6). The lateral (ay) body of the machine and vertical acceleration (axe) are calculated using Equations (7) and (8). The mass of $\mathrm{mP}$ and $\mathrm{mC}$ associated with engine vibration is determined by both equations, which have a significant role. The mass of the piston $(\mathrm{mP})$, crankshaft $(\mathrm{mC})$, and the connecting rod can be reduced by using guidance on the engine block so that the vertical speed (ax) can be reduced. The $\mathrm{mC}$ mass may affect lateral acceleration (ay). One of the most important factors on the cylinder is pressure fluctuation, $\mathrm{P}(\mathrm{x})$.

$$
\begin{aligned}
& \mathrm{a}_{\mathrm{x}}=\frac{\left(m_{p}+m_{c}\right) r \omega^{2} \cos \omega t+m_{p} \frac{r^{2} \omega^{2}}{l} \cos 2 \omega t+P(x) \cdot A}{\left(m_{\text {engine }}-m_{p}-m_{c}\right)} \\
& \mathrm{a}_{\mathrm{y}}=\frac{-m_{c} r \omega+\text { Piston Slap }}{\left(m_{\text {engine }}-m_{c}\right)}
\end{aligned}
$$


A few researchers have studied the effect of vibration on the engine specifically on private vehicles fuelled using various gasoline combinations; however, generally, the experiments are carried out on single cylinder diesel engines. The fuel used for the tests is also still dominated by diesel and biodiesel, while alcohol-based fuels are still very little found in the literature especially for four-cylinder engines. Experiments using ethanol-gasoline fuels as well as ethanol-methanol blends such as the results of researches conducted by $[8,16]$ suggested that the vibrations and noise on the engine can be significantly reduced as compared to using diesel. Several previous studies on the effects of vibration on the engine using various fuel mixtures and the results that have been reported can be seen in Table 3 .

Some researchers around the world have investigated the noise effects on engines, but very little is found for investigations with regard to gasoline engines. Among the many studies, there is only a fraction of which discusses a single cylinder engine using an alcoholbased fuel mixed into gasoline or other alcohols. The use of alternative fuels is a very appropriate step to do for now, because in addition to petroleum that is increasingly thinning, it can also reduce noise in the engine. Alcohol fuel has a higher heat value than diesel, so both the noise and vibration of the engine can be significantly reduced, as proven by the studies conducted by $[8,16]$. Noise or vibration reduction is also found in mixtures of biodiesel fuel mixed into diesel because biodiesel is a renewable energy that has a high latent heat value just like alcohol and gasoline. However, if pure diesel is used, the noise and vibration generated are very high. Hence, in the future, the use of alternative fuels becomes an excellent choice, but the use of alternative fuels today is still very minimal due to the high price and lack of attention from the government.

Table 3. Effect vibration on the engine using fuel blends

\begin{tabular}{|l|c|l|c|}
\hline \multicolumn{1}{|c|}{ Fuel } & Vibration/Noise & \multicolumn{1}{|c|}{ Finding } & Ref \\
\hline $\begin{array}{l}\text { Ethanol- } \\
\text { Diesel }\end{array}$ & Decrease & $\begin{array}{l}\text { The blended fuel (D94E6) can increase RMS and vibration } \\
\text { kurtosis in 4.75\% and 7.75\% engine blocks as compared to pure } \\
\text { diesel. }\end{array}$ & {$[9]$} \\
\hline $\begin{array}{l}\text { Diesel- } \\
\text { Biodiesel }\end{array}$ & Decrease & $\begin{array}{l}\text { The highest vibration amplitude is found in the B20 fuel with a } \\
\text { load of } 100 \text { Nm of 35\%. While the lowest vibration vibrations are } \\
\text { found at 300 and 400 N loads, using biodiesel. }\end{array}$ & {$[18]$} \\
\hline $\begin{array}{l}\text { Diesel- } \\
\text { Biodiesel }\end{array}$ & Decrease & $\begin{array}{l}\text { The correlation level (R) values for vibration and noise are an } \\
\text { average of 0.784 and 0.741. }\end{array}$ & {$[17]$} \\
\hline $\begin{array}{l}\text { Diesel- } \\
\text { Biodiesel- } \\
\text { Hydrogen }\end{array}$ & Decrease & $\begin{array}{l}\text { The addition of gas will decrease the vibration in the machine, } \\
\text { while the sound pressure changes after the addition of H2. }\end{array}$ & {$[14]$} \\
\hline $\begin{array}{l}\text { Diesel- } \\
\text { Biodiesel }\end{array}$ & Increase & $\begin{array}{l}\text { The highest value is found on B10 on all machine loads, while the } \\
\text { opposite results are seen in B40. }\end{array}$ & {$[11]$} \\
\hline $\begin{array}{l}\text { Diesel- } \\
\text { Jatropha } \\
\text { biodiesel }\end{array}$ & Increase & $\begin{array}{l}\text { The duration of combustion and variation of HRRmax is very well } \\
\text { correlated with the presence of vibration and noise measurements. }\end{array}$ & {$[28]$} \\
\hline $\begin{array}{l}\text { Ethanol- } \\
\text { Gasoline }\end{array}$ & Decrease & $\begin{array}{l}\text { The use of ethanol and gasoline fuels can reduce engine vibration } \\
\text { and noise; this decrease is due to higher latent heat values. }\end{array}$ & {$[16]$} \\
\hline $\begin{array}{l}\text { Ethanol- } \\
\text { Methanol }\end{array}$ & Decrease & $\begin{array}{l}\text { The vibration amplitude decreases by about } 1,500 \text { Hz by using a } \\
\text { fuel mixture of } 10 \%, 20 \% \text { and 30\% at 1,000, 1,300, and 1,600 rpm } \\
\text { velocities. }\end{array}$ & {$[8]$} \\
\hline $\begin{array}{l}\text { Diesel- } \\
\text { biodiesel }\end{array}$ & Decrease & $\begin{array}{l}\text { The lowest vibrations are found on the B100, B5, and B20 fuels, } \\
\text { while the highest values are in B15 and B10. }\end{array}$ & {$[10]$} \\
\hline $\begin{array}{l}\text { Biodiesel- } \\
\text { Diesel }\end{array}$ & Decrease & $\begin{array}{l}\text { Acceleration of vibration in the combustion engine can be derived } \\
\text { with the use of biodiesel-hydrogen. }\end{array}$ & {$[13]$} \\
\hline
\end{tabular}




\begin{tabular}{|l|l|l|l|}
\hline $\begin{array}{l}\text { Biodiesel } \\
\text { and } \\
\text { Petrodiesel }\end{array}$ & Increase & $\begin{array}{l}\text { The highest vibration is in fuels B15, B30, and B50. However, } \\
\text { vibrations are always consistent at different engine speeds. }\end{array}$ & {$[12]$} \\
\hline
\end{tabular}

\section{The result from previous researches}

Figures 5 and 6 are experimental results showing vibration and noise effects when using a mixture of biodiesel fuel with diesel, where the highest vibration amplitude is found in the B50 fuel with an engine load at $100 \mathrm{Nm}$ lower by $35 \%$ as compared to pure diesel. While at machine loads reaching $200 \mathrm{Nm} 300 \mathrm{Nm}$ with fuel B100, the vibration amplitude was found to be higher up to $11 \%$ and $19 \%$ than diesel. Meanwhile, the average value of noise when using diesel fuel reaches $21.2 \%$, which is much higher than the value for fuel mixture B20 for $200 \mathrm{Nm}$ load. Fuels B50 and B20 have an average noise value of 18\% at a load of 300 $\mathrm{Nm}$ higher than diesel fuel. Thus, in general, diesel fuel is higher than biodiesel, especially at $100 \mathrm{Nm}$ machine load.

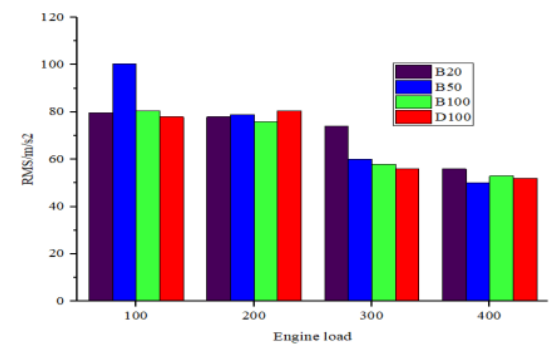

Fig. 5. Vibration for different load

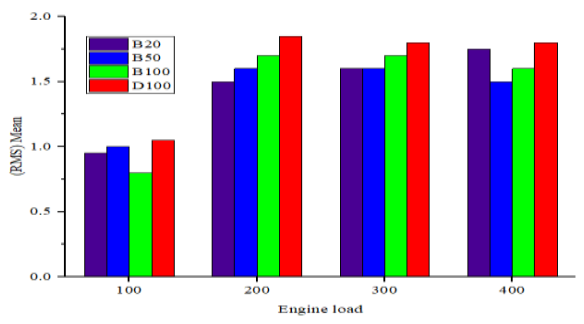

Fig. 6. Noise for different load

\section{Conclusion}

The main focus of this critical review is to analyse the results of vibration and noise on the engine by employing a form of fuel blends. Several papers documented during this study have investigated the effects of vibration and noise on the combustion engine:

- Investigations about the effects of vibration and noise on machines have generally been conducted by using diesel and biodiesel fuel.

- $\quad$ The effects of vibration and noise slightly decreased when using biodiesel fuel as compared to pure diesel, because biodiesel has higher heat levels than diesel.

- $\quad$ The D94E6 fuel mixture showed the RMS and vibration kurtosis contained in the engine block increased $4.75 \%$ and $7.75 \%$ as compared to pure diesel fuel, while an increase was found in the average torque of $3.8 \%$. 
- The experiments with the ethanol-gasoline blend with volumes of $25 \%$ E-70\% G-5\% $\mathrm{O}$ and $50 \% \mathrm{E}-45 \% \mathrm{G}-5 \% \mathrm{O}$, at 1,500 and 2,500 rpm engine speeds showed the characteristics of vibration changes significantly.

The authors would like to acknowledge for the University Malaysia Pahang (UMP) financial support through short-term research grant scheme (RDU172204, RDU130131 and UMP Grant RDU 180335).

\section{References}

1. F Wasbari, RA Bakar, LM Gan, MM Tahir, A.A.Yusof. Renew. Sustain. Energy Rev, 67 (2017).

2. Z Zhang, J Wang, X Feng, L Chang, Y Chen, XingguoWang Renew. Sustain. Energy Rev, 91(2018).

3. Y Yu, NG Naganathan, RV Dukkipati. Mech. and Mach. Theory, 36 (2001).

4. HG How, HH Masjuki, MA Kalam, YH Teoh, HG Chuah. Fuel, 227 (2018).

5. HG How, HH Masjuki, MA Kalam, YH Teoh. Energy,. 69 (2014).

6. A Elfasakhany. Eng. Sci. Technol. an Int. J., 19(2016).

7. GDJG Peña, YA Hammid, A Raj, S Stephen, T Anjana.. Fuel, 222(2018).

8. I Gravalos, S Loutridis, D Moshou, T Gialamas, D Kateris, Z Tsiropoulos, P Xyradakis. Appl. T. Eng, 54 (2013).

9. A Taghizadeh-Alisaraei, A Rezaei-Asl. Fuel, 185 (2016).

10. B Heidary, SR Hassan-Beygi, B Ghobadian, A. Taghizadeh. Agr. Eng. Int:CIGR Journal, 15 (2013).

11. G Chiatti, O Chiavola, F Palmieri. App. Energy, 185 (2017).

12. A Taghizadeh-Alisaraei, B Ghobadian, TT Hashjin, Mohtasebi. Fuel, 102 (2012).

13. K Çelebi, E Uludamar, M Özcanlı. Int. Journal of Hyd. Eng, 42 (2017).

14. E Uludamar, Ş Yıldızhan, K Aydın, M Özcanlı, Int. Journal of Hyd. Eng, 1(2016).

15. C Patel, S Lee, N Tiwari, AK Agarwal, CS Lee, S Park. Fuel, 185 (2016).

16. A Keskin - Energy Sources, 32 (2010).

17. E Uludamar, E Tosun, K Aydın. Fuel, 177:( 2016).

18. Çınar, A., Conference: ICAME Istanbul (2015).

19. TL Alleman, RL McCormick, ED Christensen, G Fioron, M Kristi; Y Janet, OSTO.GOV. (2016).

20. M Tomassetti, R Angeloni, G Merola, M Castrucci. Elect. Act, 191 (2016).

21. M Matzen, Y Demirel. J.C Production, 139 (20160.

22. C Fan, C Song, G Lv, G Wang, H Zhou, X Jing. App. Ther. Eng, 129 (2018).

23. Z Dou, C Yao, H Wei, B Wang, M Liu, C Chen, J Gao. Fuel, 192 (2017).

24. OI Awad, R Mamat, OM Ali, NAC Sidik, T Yusaf. Renew. Sustain. Energy Rev., 82 (2018).

25. IM Yusri, R Mamat, G Najafi, A Razman, OI Awad. Renew. Sustain. Energy Rev., 77 (2017).

26. IM Yusri, R Mamat, G Najafi, A Razman, OI Awad. Renew. Sustain. Energy Rev, 77 (2017). 
27. Erdiwansyah, R. Mamat, M.S.M. Sani, A. M. Norkhizan, L. Mulyadi. JBETE, 4 (2018).

28. C Patel, S Lee, N Tiwari, AK Agarwal, CS Lee, S Park. Fuel, 185 (2016). 